
\title{
Psychoacoustic Study:
}

\section{Mapping of Language Deviation in Down Syndrome Children}

\author{
Tri Wahyu Retno Ningsih \\ English Letters Department \\ Gunadarma University \\ Jakarta, Indonesia \\ twahyurn@gmail.com
}

\author{
Dyah Cita Irawati \\ Technological Information Department \\ Gunadarma University \\ Jakarta, Indonesia \\ dyahcita@staff.gunadarma.ac.id
}

\author{
Ichwan Suyudi \\ English Letters Department \\ Gunadarma University \\ Jakarta, Indonesia \\ ichwan@staff.gunadarma.ac.id \\ Sunarti Desrieny Tambunan \\ English Letters Department \\ Gunadarma University \\ Jakarta, Indonesia \\ sunarti_tambunan@staff.gunadarma.ac.id
}

\begin{abstract}
Down syndrome is an underdevelopment physical and mental condition in children caused by chromosomal development abnormalities. Signs that show from down syndrome may vary from the invisible, slightly visible to a typical sign of down syndrome. The most typical sign of children with Down syndrome is the children's underdevelopment of physical and mental condition (Olds, London, \&Ladewing, 1996). Down syndrome sufferers are very easily recognizable by the presence of a prominent physical appearance where the head is relatively smaller than normal head (microcephaly) with (anteroposterior) the head flattened. On the face usually can be seen from the flat and low bridge nose, the mouth is smaller and the tongue slightly larger and sometimes protrudes out (macroglossia). The eyes slant upwards and have an extra fold of skin on the upper eyelid (epicanthic folds). Down Syndrome children also have sensory difficulties, speaking barriers, and verbal development. This study aims to identify the speech impairment disorder in Down Syndrome children. The research method used is mix methods. The data source is conversation which produced by Down Syndrome children's aged 8-10 years old. The results showed that DS children had an indication of disruption (1) voice production, i.e. noise production to communicate verbally, (2) disruption in speech sounds, i.e. disruption in phoneme production on certain vowels and consonants, and (3) fluency and prosody, i.e. pitch production, duration and formants.
\end{abstract}

Keywords - down syndrome; voice production; speech sounds; formants; prosody

\section{INTRODUCTION}

Language difficulties are common to Down Syndrome (DS) children. Their language skills are usually below other children's mental abilities in general. Unclear speech and false errors are more common in DS children than others. The speaking barrier is getting worse if there is mental retardation, motor oral deficit, sensory deficit, or environmental deprivation. Often, language disorder in DS children is associated with the mental level of the children's abilities so that their language development does not fit the context of ongoing communication.
DS children is also obstructed in academic ability. Specifically this academic barrier is the impact of the limitations of cognitive ability. Ashman (1983) suggests that children who are classified as having mild and moderate mental retardation have problems in processing information to integrate or generalize information. Early stimulation is believed to improve the intelligence of DS children. One of the medical seminars stated that children who experience DS have a low Intelligence Quotient (IQ). However, now, by giving regularly and intensively early detection and stimulation, the intelligence of children with DS can be improved sub normally between 70-90.

Down Syndrome (DS) is a genetic condition that causes a child's inability to learn because of his physical characteristics. Children with Down syndrome are characterized by limited mobility due to their weak muscle tissue (hypotonia), protruding eyes, small mouths with tongue sticking out, and flat rear heads. These children also have limited cognition making it difficult to process information that related to routines. They also have limitations to adapt to the environment and tasks, and tend to rely on others (Lewis, 2000).

One of the disruption inherent in DS children is a language disorder associated with physical characteristics in the linguistic sound organ and disruption of the cognitive aspects. Therefore, language development in DS children shows significant differences with children who develop normally. Based on data sources in the field mentioned that the prevalence of DS children tends to increase, with the calculation between 700 births or 1 in 800-1000 births and estimated there are four million DS sufferers worldwide, and 300 thousand cases in Indonesia. Increased DS prevalence and surrounding disorders are increasing, but in-depth studies of language disorders, especially phonology and phonetics have not been done so these area are interesting to examine.

The Stoel-Gammon (2001) study of language disorders in DS children shows that these children have a phonological 
disorder or language system, such as cluster reduction, final consonant removal, stop, prevocalic voice, glinding, vocalization, and final consonant devoicing. These speech disorders, detected from mild to severe levels. Rupela and Manjula (2007) examined the phonotactic pattern of Down Syndrome children and compared them with Specific Language Impairment (SLI) children and found that DS children were only able to use simple phonotactic patterns and often eliminate the attributes of vowel sounds or consonant sounds or characterized by atypical speech error. Some researchers consider that atypical error of speech tends to be caused by a delay in the development of phonological systems in children.

Based on these descriptions, there is a relationship between the phases of children's developmental disorders, language development disorders, and academic disorder in DS children. The condition of Down Syndrome that is attached to a child will affect the level of maturity of its development that distinguishes it from the development of children in general. However, by having the knowledge to recognize the normal developmental stage that children go through in general, parents can get the disorder description in each child, especially the language disorder.

This study aims to provide an overview of the ability of sound language production and formant structure in children with Down Syndrome using acoustic phonetic analysis. Phonetics is the study of how the sound of the language is formed, the frequency of vibration, intensity, and its timbre, and how the sound of the language can be accepted by the ear. Based on the breadth of the scope of phonetic studies, phonetics are divided into three types, namely organic phonetics, acoustic phonetics and auditor phonetics (O'Grady and Archibald, 2000: 13). According to Yulianto and Tirtawijaya (1989: 25) acoustic phonetics is the most exact phonetic because it is based on the discovery of physics and mathematical discoveries. Acoustic phonetics investigates the sound waves that vibrate the air around which the ear hears as the language sounds. Malmberg, Bertil (1963: 20) says that what is learned in the field of acoustic phonetics is the sound of language in terms of sound as physical phenomena, such as studying the frequency of vibration, amplitude, intensity, and its timbre (fig. 1)

\section{- articulatory phonetics}

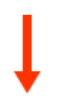

- acoustic phonetics

- auditory phonetics
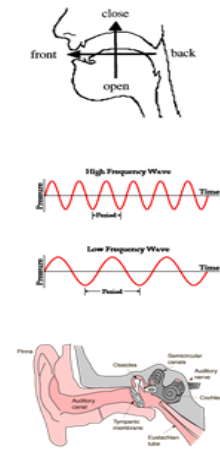

Fig.1. Phonetic domain

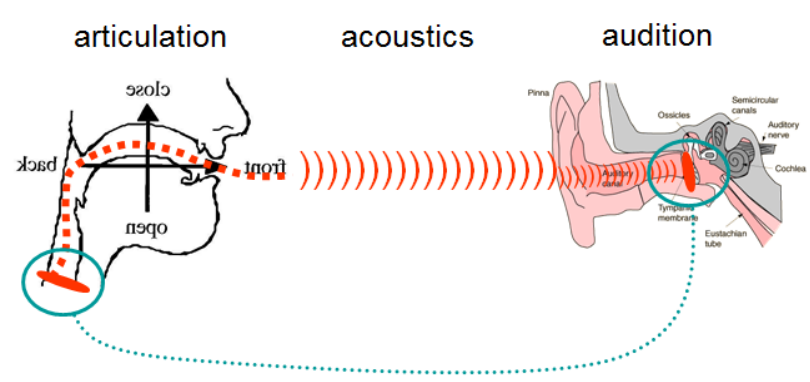

Fig. 2. Acoustic perception process

According to Marsono (1999: 3) this acoustic phonetic has much to do with physics in phonetic laboratories, this is also useful in producing telephone calls, recording records and so on. To measure the frequency of air vibrations in the form of waves as a used tool called oscillography. Similar tools then emerge, such as spectrograms, which allow us to know the acoustic quality of the said sounds to be analyzed (Yusuf, Suhendra, 1998: 35). Next comes a tool called Praat program. When a speech is recorded and then inserted into Praat program and from the sound wave, it can be recognized the characteristic of speech sound image.

One of the analysis that will be done is formant analysis. Formants are the resonant frequencies of the filter, the vocal tract (articulator) that continues and filters out the vowel, consonant, or word output. Cohn in Aronoff and Janie (2003), explains that the vowel sounds in general have characteristics in terms of the height of the tongue or jaw (high, medium, low) and the moving part of the tongue (front, center, back). In addition, the vowel sounds appear because the utterance is not too close so the airflow does not experience any obstacles (Ladefoged and Johnson, 2011). Ladefoged and Johnson (2011) explain that vowel sounds are better explained by explanation of acoustic structures than by explaining the effect of articular movements.

The production ability of speech sounds that emphasized in this research is the sound of language which is part of the phonological and phonetic processes. Therefore, the theoretical frames of this study are theories summarized in the synchronous study in acoustic, articulatory, and psychoacoustic phonetic studies.

\section{RESEARCH METHOD}

The research method used is experimental phonetic analysis. Source of data used is the speech production by children with down syndrome, age 8 years old. The research method used is acoustic study (van Zanten and van Heuven, 1983). The production process is done through recording of DS children. The recording process is done using a Sony recorder with an ideal recording distance and natural. Data were analyzed using Praat software (formant analysis), to generate F0 value, formant value, and duration value on each word produced. The research flowchart is described in Figure 3. 


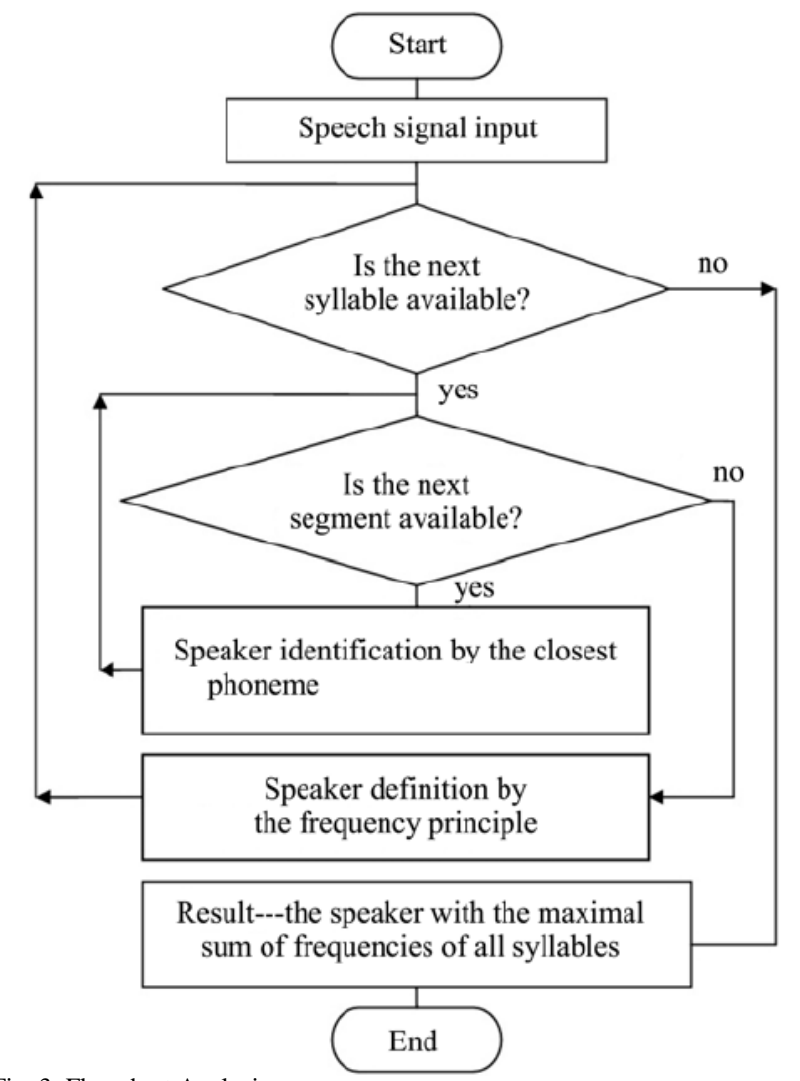

Fig. 3. Flowchart Analysis

\section{RESULT AND DISCUSSION}

Based on the findings of data obtained from this study, it can be explained that the ability of DS children in expression is low because they can only say something at the level of words or syllables, not to the level of morphology, syntax or discourse. The following is the result of acoustic analysis on the word 'bahu' (shoulder).

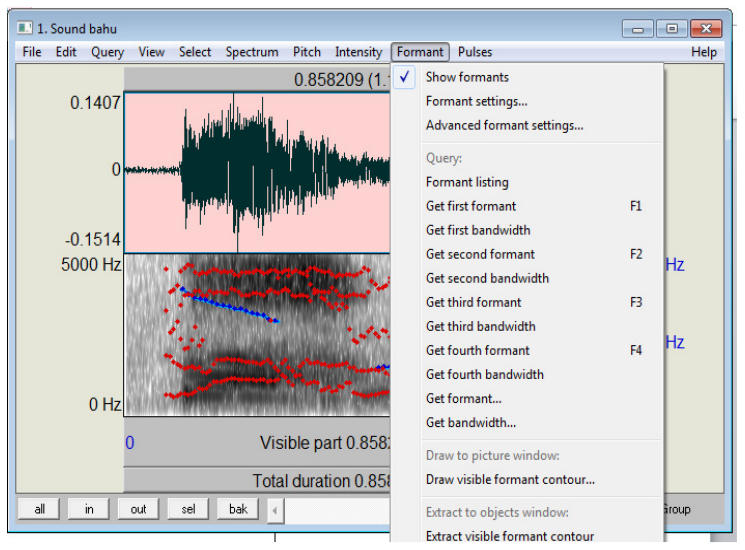

Fig. 4. Formant Analysis

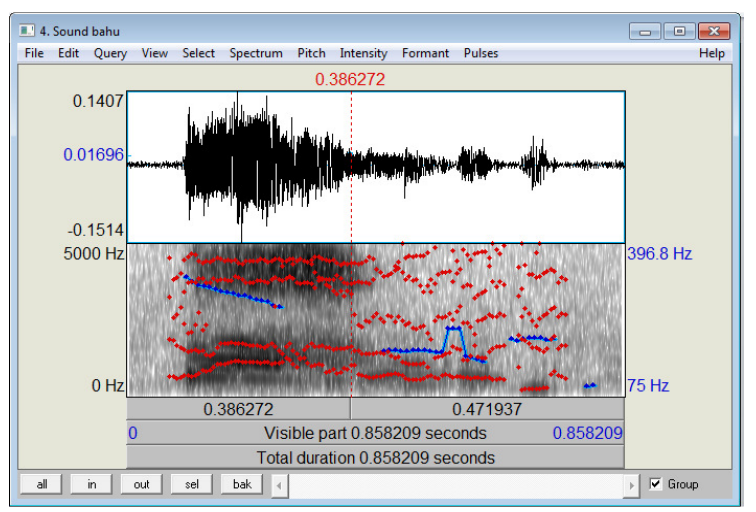

Fig. 5. Analysis of pitch movement on the word 'bahu' (shoulder)

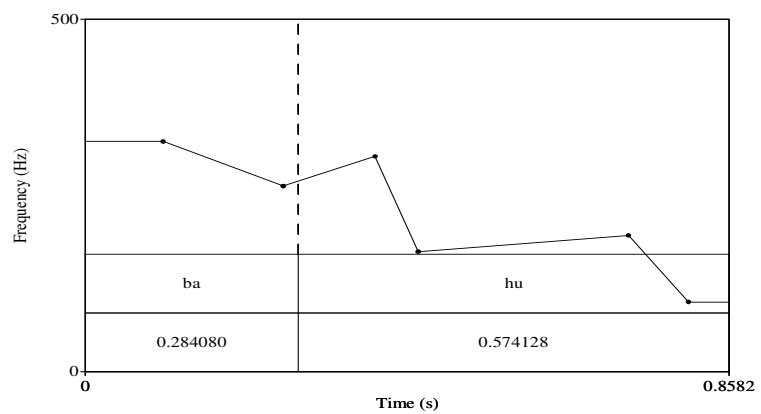

Fig. 6. Formant analysis of the word 'bahu' (shoulder)

Fig. 3 illustrates the acoustic analysis to obtain formant values $(\mathrm{F} 1, \mathrm{~F} 2$, and F3). Formant value is shown in red tone pattern, while blue indicates F0.

Examples of words produced in this study are the words 'mata' (eye), 'dada' (chest), 'lengan' (arms), 'tangan' (hands), 'kepala' (head), and 'kelapa' (coconut). 'mata' (eyes), 'dada' (chest), 'lengan' (arms), 'tangan' (hands) have two syllables of $\mathrm{CV}-\mathrm{CV}$ and CV-CV. The word 'kepala' (head) and 'kelapa' (coconut) have 3 syllables, namely CV-CV-CV.

The result of acoustic analysis on said data is described in figure 7 .

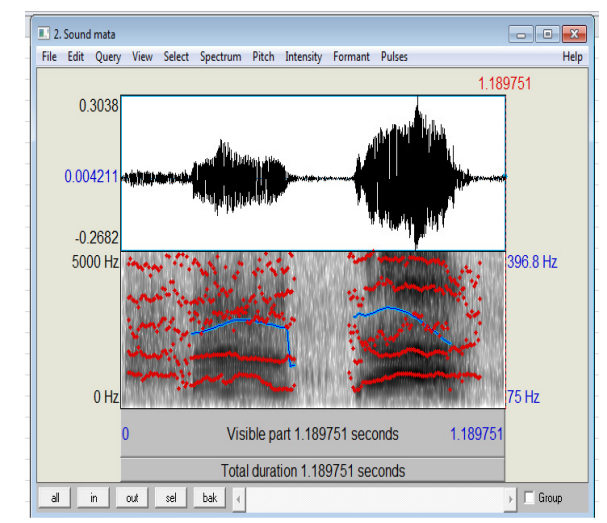

Fig 7. Acoustic analysis of the word 'mata' (eyes) 


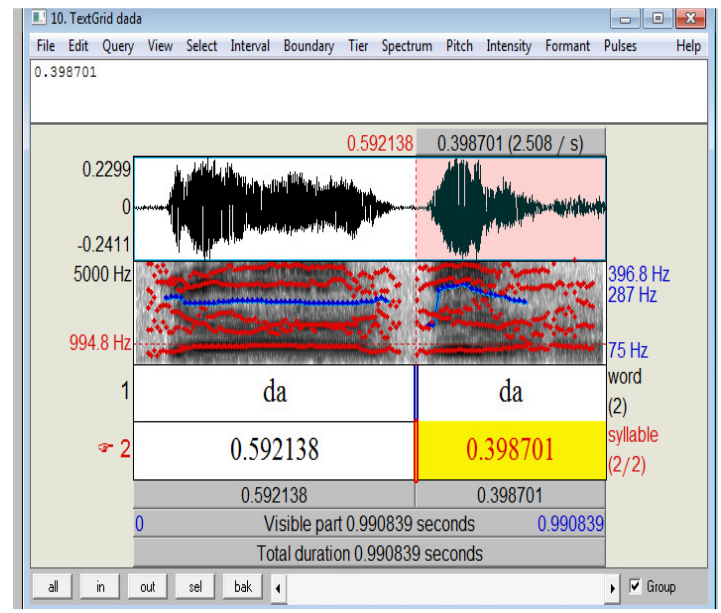

Fig. 8. Acoustic value on the word 'dada' (chest)

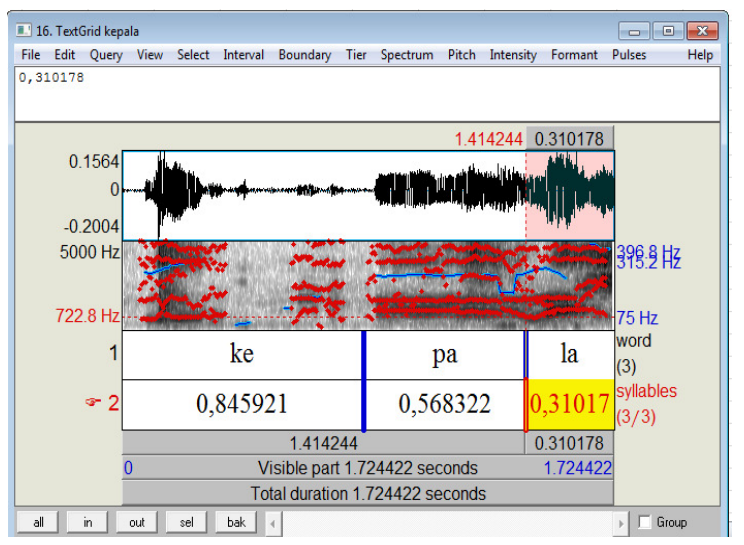

Fig. 9. Acoustic analysis of the word 'kepala' (head)

The result of the acoustic analysis of each word is described in the following:

TABLE 1. F0 VALUE OF THE WORD (DADA (HEAD), MATA (EYE (S), AND PAHA (THIGH))

\begin{tabular}{|c|c|c|c|}
\hline Words said & Mean F0 (Hz) & F0 minimum $(\mathrm{Hz})$ & $\begin{array}{c}\text { F0 maximum } \\
(\mathrm{Hz})\end{array}$ \\
\hline Dada & 273.536 & 192.898 & 321.777 \\
\hline Mata & 249.811 & 152.3182 & 281.903 \\
\hline Paha & 260.839 & 237.283 & 280.414 \\
\hline
\end{tabular}

F0 value analysis in the above table explains that the word 'paha' (thigh) has the highest F0 value compared to the word 'dada' (chest) and 'mata', but the difference is not significant. The lowest minimum F0 value is the word 'mata' (eye (s)), and the highest minimum F0 value is found on 'paha' (thigh). The lowest minimum F0 value is found in 'paha' (thigh), whereas the highest maximum value is found in the word 'dada' (chest).

TABLE 2. F0 VALUE OF THE WORD ('KEPALA' (HEAD) AND 'KELAPA' (COCONUT)

\begin{tabular}{|c|c|c|c|}
\hline $\begin{array}{c}\text { Words } \\
\text { said }\end{array}$ & $\begin{array}{c}\text { Mean F0 } \\
(\mathrm{Hz})\end{array}$ & $\begin{array}{c}\text { F0 minimum } \\
(\mathrm{Hz})\end{array}$ & $\begin{array}{c}\text { F0 maximum } \\
(\mathrm{Hz})\end{array}$ \\
\hline Kepala & 266.362 & 92.6179 & 381.839 \\
\hline Kelapa & 194.873 & 144.319 & 341.228 \\
\hline
\end{tabular}

F0 value analysis on table above explains that the word 'kepala' (head) has a higher F0 value than the word 'kelapa' (coconut), while the minimum F0 value in the word 'kelapa' (coconut) is the lowest compared to the word 'kepala' (head). F0 value of the word 'kelapa' (coconut) is lower than the word 'kepala' (head).

TABLE 3. F0 VALUE OF THE WORD ('TANGAN' (HANDS) AND 'LENGAN' (ARMS))

\begin{tabular}{|c|c|c|c|}
\hline $\begin{array}{c}\text { Words } \\
\text { said }\end{array}$ & \multicolumn{1}{|c|}{$\begin{array}{c}\text { Mean F0 } \\
(\mathrm{Hz})\end{array}$} & $\begin{array}{c}\text { F0 minimum } \\
(\mathrm{Hz})\end{array}$ & $\begin{array}{c}\text { F0 maximum } \\
(\mathrm{Hz})\end{array}$ \\
\hline Tangan & 148.856 & 94.622 & 205.070 \\
\hline Lengan & 182.549 & 75.444 & 260.765 \\
\hline
\end{tabular}

The F0 value analysis in the table above explains that the word 'lengan' (arms) has a higher F0 value than the word 'tangan' (hand), while the minimum F0 value of the word 'tangan' (hand) is lower than the word 'lengan' (arms). The value of F0 of the word 'lengan' (arms' is lower than the word 'tangan' (hand).

TABLE 4. FORMANT ANALYSIS OF THE WORD ('DADA' (CHEST), 'MATA' (EYE (S)), AND 'PAHA' (THIGH))

\begin{tabular}{|l|l|l|c|}
\hline $\begin{array}{c}\text { Words } \\
\text { said }\end{array}$ & F1 $(\mathrm{Hz})$ & F2 $(\mathrm{Hz})$ & F3 (Hz) \\
\hline Dada & 714.096 & 1680.952 & 3774.428 \\
\hline Mata & 923.803 & 1766.375 & 2721.560 \\
\hline Paha & 974.323 & 1841.008 & 2883.671 \\
\hline
\end{tabular}

F1 value analysis on the word 'dada' (chest) is 714.096 $\mathrm{Hz}$, 'mata' (eye (s)) is $923.803 \mathrm{~Hz}$, and 'paha' (thigh) is $974.323 \mathrm{~Hz}$. The value of F2 on the word 'dada' (chest) is $1680.952 \mathrm{~Hz}$, the word 'mata' (eye (s)) is $1766.375 \mathrm{~Hz}$, and the word 'paha' (thigh) is $1841.008 \mathrm{~Hz}$.

TABLE 5. FORMANT ANALYSIS OF THE WORD ('KEPALA' (HEAD) AND 'KELAPA' (COCONUT))

\begin{tabular}{|c|c|c|c|}
\hline $\begin{array}{c}\text { Words } \\
\text { said }\end{array}$ & F1 $(\mathrm{Hz})$ & F2 $(\mathrm{Hz})$ & F3 $(\mathrm{Hz})$ \\
\hline Kepala & 856.979 & 1650.006 & 2768.213 \\
\hline Kelapa & 863.898 & 1599.721 & 2975.511 \\
\hline
\end{tabular}

Acoustic analysis on the word 'kepala' (head) is 856.979 $\mathrm{Hz}$, while the word 'kelapa' (coconut) has a value of 863,898 $\mathrm{Hz}$. The value of F2 on the word 'kelapa' (coconut) is higher than the word 'kepala' (head).

TABLE 6. FORMANT ANALYSIS OF THE WORD ('TANGAN' (HANDS) AND 'LENGAN' (ARMS))

\begin{tabular}{|l|l|l|l|}
\hline $\begin{array}{l}\text { Words } \\
\text { said }\end{array}$ & F1 $(\mathrm{Hz})$ & F2 $(\mathrm{Hz})$ & F3 $(\mathrm{Hz})$ \\
\hline Tangan & 716.411 & 1466.868 & 2368.426 \\
\hline Lengan & 740.017 & 1617.333 & 2600.765 \\
\hline
\end{tabular}

The acoustic analysis on 'tangan'(hand) is $716.411 \mathrm{~Hz}$, while the word 'tangan'(arm) has a value of 740,017 Hz. The value of F2 in said 'tangan'(arm) is higher by 1617,333 compared to the word 'tangan' (hand) (1466868). 


\section{References}

Aaltonen, O. (1985). The effects of relative amplitude levels of F2 and F3 on the categorization of synthetic vowels. Journal of Phonetics, 13, 1-9.

Aronoff, Mark, and Janie Rees-Miller [eds.]. 2003. The handbook of linguistics. (Blackwell handbooks in linguistics). Oxford: Blackwell.

Answorth, W. A. (1981). Duration as a factor in the recognition of synthetic vowels. Journal of Phonetics, 9, 333-342.

Cohen, W. I., Nadel, L., \& Madnick, M. E. (2002). Down Syndrome Visions for the 21st Century. New York: Wiley-Liss, Inc.

Fant, C.G. (1956). On the predictability of formant levels and spectrum envelops from formant frequencies. In $\mathrm{M}$. Halle, H. G. Lunt, H. McLean, \& C. H. Van Schooneveld (Eds.), For Roman

Gottfried, T. L. \& Beddor, P. S. (1988). Perception of temporal and spectral information in French vowels. Language and Speech, 31, 57-75.

Hillenbrand, J. M.; Getty, L. A.; Clark M. J.; Wheeler K. (1995). Acoustic characteristics of American English vowels. Journal of the Acoustical Society of America, 97, 3099-3111.

Hunt, L., Lewis, D., Reisel, S., Waldrup, L. \& Wooster, D.M.A. (2000). Age Norms for Straw-Drinking Ability. Infant-toddler Intervention. The Transdisciplinary Journal, 10(1), 1-7.

Ladefoged, P., \& Johnson, K. (2011). A course in phonetics (6th ed.). Boston, MA: Wadsworth.

Malmberg, Bertil. 1963. Phonetics. New York: Dover Publications.

Marsono. (1999). Fonetik. Yogyakarta: Gadjah Mada University Press.

Miller, R. L. (1953). Auditory tests with synthetic vowels. Journal of the Acoustical Society of America, 25, 114121.

Nearey, T. M. (1989). Static, dynamic and relational properties in vowel perception. Journal of the Acoustical Society of America, 85, 2088-2113.

O'Grady, William, dan Michael Dobrovolsky. 2000. Contemporary Linguistic Analysis: An Introduction. Ontario: Copp Clark Pitman Ltd.

Olds SB, London ML, Ladewig PAW. (2000). Maternal New Born Nursing: a family and community based approach. Sixth edition. New Jersey: practice Hall Health

Peterson G. E. \& Barney, H. L. (1952). Control methods used in a study of the vowels. Journal of the Acoustical Society of America, 24, 175-184.

Pruthi, G. (2007). Language Development in Children with Mental Retardation. [Online] Tersedia : http://goertzel. org/dynapsyc/2007/Language\%20 development.htm [07 Januari 2015]204

Stoel-Gammon, C. \& Pollock, K. (2008). Vowel development anddisorders. In M. J. Ball, M. R. Perkins, N. Muller, \& S. Howard(Eds.) The Handbook of
Clinical Linguistics (pp. 525-548).Oxford: Blackwell Publishing

Yulianto, Bambang. 2010. Penggunaan cara walikan dalam bahasa Jawa dialek Tuban: Kajian fonologi generatif. Laporan penelitian fundamental lanjutan. Surabaya: Kementerian Pendidikan Nasional, Republik Indonesia, Universitas Negeri Surabaya, Lembaga Penelitian.

Yusuf, Suhendra. (1998). Fonetik dan Fonologi. Jakarta: Gramedia Pustaka Utama

Van Zanten, E , and V J van Heuven 1983 A phonetic analysis of the Indonesian vowel system A prehminary acoustic study', NUSA, Linguistic Studies of Indonesian and Other Languages in Indonesia, 15 70-80.

Vani Rupela, R. Manjula \& Shelley L. Velleman (2009). Phonological processes in Kannada-speaking adolescents with Down syndromePages 431-450 I Received 15 Mar 2009, Accepted 29 Oct 2009, Published online: 06 Feb 201 